УдК 338.26

\title{
РЕГЛАМЕНТАЦІЯ СТРАТЕГІЧНОГО ПЛАНУВАННЯ РОЗВИТКУ ЕКОНОМІЧНОЇ СИСТЕМИ В УКРАЇНІ
}

\section{REGULATION OF STRATEGIC PLANNING OF ECONOMIC SYSTEM DEVELOPMENT IN UKRAINE}

\author{
Канова Олександра Андріївна \\ кандидат економічних наук, \\ Харківський національний економічний університет імені Семена Кузнеця \\ ORCID: https://orcid.org/0000-0002-0101-053X
}

Kanova Oleksandra

Simon Kuznets Kharkiv National University of Economics

\begin{abstract}
Стаття присвячена узагальненню сутності понять «стратегія» та «стратегічне планування» в контексті розвитку економічної системи держави; досліджено сутнісні властивості, що вкладають сучасні науковці в трактування даних категорій. Визначено ставлення провідних фрахівців України щодо стану розвитку системи стратегічного планування в державі. Досліджено правове поле України, яке регламентує питання стратегічного планування розвитку економічної системи держави. Узагальнено нормативно-правове забезпечення стратегічного планування розвитку економічної системи держави в Україні на загальнодержавному рівні, а також на регіональному та місцевому рівнях. Визначені ключові недоліки існуючої системи регламентації стратегічного розвитку економічної системи України.

Ключові слова: нормативно-правова регламентація, планування, розвиток економічної системи, стратегічне планування, стратегія.

Статья посвящена обобщению сущности понятий «стратегия» и «стратегическое планирование» в контексте развития экономической системы государства; исследованы сущностные свойства, которые вкладывают современные ученые в трактовку данных категорий. Определены отношения ведущих специалистов Украины о состоянии развития системы стратегического планирования в государстве. Исследовано правовое поле Украины, регламентирующее вопросы стратегического планирования развития экономической системы государства. Обобщено нормативно-правовое обеспечение стратегического планирования развития экономической системы государства в Украине на общегосударственном уровне, а также на региональном и местном уровнях. Определены ключевые недостатки существующей системы регламентации стратегического развития экономической системы Украины.
\end{abstract}

Ключевые слова: нормативно-правовая регламентация, планирование, развитие экономической системы, стратегическое планирование, стратегия.

The main goal of this article is to generalize the existing theoretical approaches to the interpretation of the essence of strategic planning for the development of the economic system of the state, as well as to study the regulatory framework governing this process in Ukraine. The article is devoted to the generalization of the essence of the concepts of «strategy» and «strategic planning» in the context of the development of the economic system of the state; it explores the essential properties that modern scientists contribute in the interpretation of these categories. The paper considers generalized approaches to understanding the concept of «strategy», which consider strategy as an abstract norm of activity, strategic action plan and as a process. The attitude of the leading specialists of Ukraine to the conditions of the strategic planning system development in the country is determined. Most scientists agree on a fairly high level of elaboration of this issue, despite the fact that some areas of forecast and planning documents are not regulated at a sufficient level. The legal field of Ukraine, which regulates the issues of strategic planning for the development of the state economic system, has been studied. It consists of general methodological documents that regulate its development, documents on which strategic plans are formed at the national level, legal acts aimed at developing and implementing strategies for regional development and territorial communities, and normative documents at the regional level and at the level of local self-government. The normative and legal support of strategic planning for the development of the state economic system in Ukraine at the national level, as well as at the regional and local levels is generalized. A brief description of key regulations governing the strategic planning of 
socio-economic development of the state is provided. The basic principles of development of strategic documents and key indicators to be studied during the preliminary analysis are identified. The key shortcomings of the existing system of regulation of strategic development of the economic system of Ukraine are identified.

Keywords: normative and legal regulation, planning, development of economic system, strategic planning, strategy.

Постановка проблеми. Ефрективне управління соціально-економічними процесами, які протікають в економічній системі держави на різних ієрархічних рівнях, неможливе без стратегічного планування, реалізація якого покладена на органи державної влади. Орієнтація лише на вирішення поточних справ та оперативне реагування на проблеми, що виникають, не може забезпечити розвиток економічної системи держави на відміну від орієнтації на довгострокові стратегічні цілі, що сприяє підвищенню ефективності управління системою національного господарства в цілому. Бекетов Н. В. зазначає, що орієнтація органів державної влади на стратегічне планування «ставить владу у нову, більш міцну позицію, у якій можливий перехід від парадигми фрункціонування до парадигми розвитку» [1, с. 16].

Аналіз останніх досліджень і публікацій. Питання планування розвитку економічних систем досліджували в своїх роботах такі науковці, як: О. Алимов, С. Біла, Б. Буркинський, М. Кизим, М. Портер, В. Хаустова, І. Ялдін, I. Ярошенко та ін. Однак єдиного трактування сутності стратегічного планування, а також методики реалізації стратегічного планування розвитку економічної системи держави наразі не існує.

Формулювання цілей статті. Метою даної роботи є узагальнення існуючих підходів до трактування сутності стратегічного планування розвитку економічної системи держави, а також вивчення нормативно-правової бази, яка регламентує даний процес в Україні.

Виклад основного матеріалу дослідження. 3 огляду на те, що в сучасній науковій літературі відсутній єдиний підхід щодо розуміння понять «стратегія», «стратегічне планування» в контексті розвитку економічної системи держави, доцільно дослідити сутнісні властивості, що вкладають різні науковці в трактування даних категорій.

Поняття «стратегія» $€$ досить широким i загальновживаним не тільки в контексті державного управління, але і в інших сорерах суспільного життя.

В роботі [9] Сментина Н. В. наводить узагальнені підходи до розуміння даного поняття:

1) стратегія як абстрактна норму діяльності, що звернена до процесів досягнення цілей. Стратегія наближується до категорії стратегічне бачення, тобто розуміється як уявлення про бажаний стан [7, с. 6];

2) стратегія як стратегічний планом дій, у цьому аспекті акцент зміщається на програмну компоненту $[7$, с. 6];

3) стратегія як процес, який спрямований на визначення напряму розвитку організації, регіону чи територіальної громади в умовах середовища, що змінюється [3, с. 4].

В даній роботі під стратегією будемо розуміти комплекс дій органів державної влади та управління складними соціально-економічними системами щодо організації діяльності суб'єктів господарювання на шляху досягнення стратегічної мети соціально-економічного розвитку відповідних територіальних утворень, які окреслені на підставі оцінки та аналізу поточної ситуації та знаходять своє відображення у плані розвитку соціально-економічної системи.

Берданова О. В., Вакуленко В. М. та ін. досліджують стратегічне планування на рівні регіонального та місцевого розвитку і надають таке визначення даному процесу: «стратегічне планування - це системна технологія обґрунтування та ухвалення найважливіших рішень щодо місцевого розвитку, визначення бажаного майбутнього стану території та способу його досягнення, що базується на ситуаційному аналізі зовнішнього оточення території та ії̈ внутрішнього потенціалу і полягає у формуванні узгоджених з територіальною громадою дій, на реалізації яких концентруються зусилля, ресурси основних суб'єктів місцевого розвитку» [8]. При цьому вони зауважують, що стратегія розвитку $€$ не всеосяжним документом, що описує всі соціально-економічні ссрери території, а сконцентрована на ключових, найбільш перспективних напрямах, які виявлені на основі аналізу соціально-економічного потенціалу, сильних і слабких сторін внутрішнього середовища території, можливих сприятливих чи негативних зовнішніх впливів. Стратегічний план, по суті, повинен стати основою для розробки різноманітних планових документів 3 тим, щоб вони узгоджувалися один з одним за цілями, загальним навантаженням на бюджет, послідовністю, заходами. Однак для виконання цієї ролі стратегічний план повинен мати юридичний статус, необхідний для впровадження його рішень в інші плани та програми [8]. 
Дацій О. І. визначає стратегічне планування як впорядковану діяльність, спрямовану на обґрунтування та прийняття важливих рішень щодо регіонального розвитку, впровадження заходів, програм та проектів, які направлені на реалізацію змін задля бажаного майбутнього стану території [2]. Качний О. С. відмічає, що стратегічне планування має бути побудоване на комунікації та участі громади, а тому сприяє врахуванню різноманітних інтересів та цінностей, прийняттю консолідованих рішень, на реалізації яких концентруються зусилля та ресурси основних учасників регіонального розвитку. Таким чином, стратегічне планування виступає інтегруючою силою, яка організовує і спрямовує процес розробки стратегічних цілей і створює основу для розподілу ресурсів на рівні регіональних органів влади [5].

Нормативно-правове забезпечення стратегічного планування соціально-економічного розвитку України сфрормовано низкою законів та інших нормативно-правових актів. Більшість авторів говорить про достатньо високий рівень опрацювання даного питання, незважаючи на те, що окремі сорери прогнозних і планових документів врегульовані не на достатньому рівні. Так, Берданова О. В. говорить про «існування системи стратегічного планування в Україні» [7]. А Федяй Н. О. відмічає на регіональному рівні достатню сорормованість нормативно-правової бази у ссрері стратегічного управління [10].

Отже, незважаючи на відсутність закону саме про стратегічне планування соціальноекономічного розвитку України (спроба підготувати закон про державне стратегічне планування була здійснена в 2011 році, однак проект закону не отримав належної підтримки), можна говорити про наявність системи стратегічного планування в Україні.

Взагалі, правове поле України, яке регламентує питання стратегічного планування розвитку економічної системи держави, поділяють на 4 блоки:

1) загально-методичні документи, які регламентують загальну методику опрацювання стратегій;

2) документи, за якими формуються стратегічні плани на загальнодержавному рівні;

3) правові акти, спрямовані на опрацювання і реалізацію стратегій регіонального розвитку та територіальних громад;

4) нормативні документи на регіональному рівні та на рівні місцевого самоврядування [3].

За іншими підходами, правове поле з даного питання поділяють за трьома рівнями: загальнодержавний, регіональний та місцевий [8].
Провідна роль в законодавстві України щодо стратегічного планування соціальноекономічного розвитку держави належить Закону України «Про державне прогнозування та розроблення програм економічного і соціального розвитку України», прийнятого в 2000 році. Відповідно до даного закону, державне прогнозування економічного і соціального розвитку визначається як науково обґрунтоване передбачення напрямів розвитку країни, окремих галузей економіки або окремих адміністративно-територіальних одиниць, можливого стану економіки та соціальної сорери в майбутньому, а також альтернативних шляхів і строків досягнення параметрів економічного і соціального розвитку. Прогноз економічного і соціального розвитку $€$ засобом обґрунтування вибору тієї чи іншої стратегії та прийняття конкретних рішень державними органами, органами місцевого самоврядування щодо регулювання соціальноекономічних процесів [6].

Розробкастратегічнихплановихдокументів з соціально-економічного розвитку здійснюється на принципах цілісності, об'єктивності, науковості, гласності, самостійності, рівності та дотримання загальнодержавних інтересів.

Програмні документи соціально-економічного розвитку розробляються на основі комплексного аналізу таких показників:

- демограсрічної ситуації;

- стану використання природного, виробничого, науково-технічного та трудового потенціалу;

- конкурентоспроможності вітчизняної економіки;

- оцінки досягнутого рівня розвитку економіки та соціальної сорери та з урахуванням впливу зовнішніх політичних, економічних та інших фракторів й очікування тенденцій зміни впливу цих фракторів у перспективі [6].

Даний закон наводить перелік планових документів, які розробляються та реалізуються в державі в середньо- та короткостроковій перспективі, проте не враховує деякі документи, які були прийняті після набуття даним законом чинності. Крім того, в ньому не наведені рівні взаємозв'язків між стратегічними плановими документами різних ієрархічних рівнів.

3 метою вдосконалення системи прогнозної і планової документації з питань соціально-економічного розвитку, в 2006 році розпорядженням Кабінету Міністрів України було схвалено «Концепцію вдосконалення системи прогнозних і програмних документів з питань соціально-економічного розвитку України» 
[4]. Даний документ визначає систему прогнозних і програмних документів, які визначають цілі і пріоритети соціально-економічного розвитку та заходи, які необхідно здійснити для їх досягнення. Такі документи поділені за періодами їх реалізації на довгострокові, середньострокові та короткострокові.

Стратегія економічного та соціального розвитку України - документ, у якому визначаються пріоритети, стратегічні цілі, структурні пропорції економіки і соціальної сорери та напрями державної політики. Стратегія розвитку галузі економіки (ссрери діяльності) - документ, у якому на основі прогнозу тенденцій розвитку відповідних ринків і напрямів науково-технічного прогресу визначаються довгострокові цілі та пріоритети розвитку галузі економіки (сорери діяльності), заходи, спрямовані на їх досягнення, та ресурси, що необхідні для здійснення таких заходів [4]. Стратегічний план роботи центрального органу виконавчої влади - це розроблений на основі стратегій розвитку відповідних галузей економіки (ссрер діяльності) документ, який визначає завдання такого органу, заходи щодо їх виконання (3 визначенням ресурсів, відповідальних за виконання, строків) та очікувані результати.

Висновки. Так, система стратегічного планування в Україні ще не сорормована остаточно, а лише перебуває на стадії свого фрормування, адже залишається безліч питань, що вимагають свого законодавчого унормування. Взаємозв'язки між окремими документами не достатньо чітко врегульовані. Деяких програмних документів не вистачає. Відсутнє єдине визначення категорій «стратегія» та «стратегічне планування», відсутні вимоги, що висуваються до стратегічних планів загальнодержавного рівня. Не дотримуються принципи пріоритетності.

\section{СПИСОК ВИКОРИСТАНИХ ДЖЕРЕЛ:}

1. Бекетов Н. В. Проблемы стратегического планирования региональным развитием. Региональная экономика: теория и практика. 2008. № 35. С. 15-19.

2. Дацій О. І. Інновації - основна діюча сила науково-технічного прогресу для збереження природного середовища. Економіка та держава. 2017. № 5. С. 4-9.

3. Дробенко Г. О., Брусак Р. Л., Свірський Ю. І. Стратегічне планування розвитку територіальних громад. Львів : Сполом, 2001. 118 с.

4. Концепція вдосконалення системи прогнозних і програмних документів з питань соціально-економічного розвитку України : Розпорядження Кабінету Міністрів України від 4.10.2006 № 504-р / Верховна Рада України. URL: https://zakon2.rada.gov.ua/laws/show/504-2006-\%D1\%80 (дата звернення: 20.10.2021).

5. Кукса І. Стратегічне планування соціально-економічного розвитку регіону. Вісник Східноукраїнського національного університету ім. В. Даля. 2016. № 17 (171). С. 218-224.

6. Про державне прогнозування та розроблення програм економічного та соціального розвитку України : Закон України від 23.03.2000 № 1602-III / Верховна Рада України. URL: https://zakon.rada.gov.ua/laws/ show/1602-14 (дата звернення: 20.10.2021).

7. Ресрорма публічного управління в Україні: виклики, стратегії, майбутнє : монограсрія / відп. ред. І. А. Грицяк. Київ : «К.І.С.», 2009. 240 c.

8. Розвиток партнерства між місцевою владою та недержавним сектором у сфері надання громадських послуг : монографія / ред. Ю. П. Лебединський. Ужгород : Патент, 2003. 192 с.

9. Сментина Н. В. Стратегічне планування соціально-економічного розвитку на мезорівні: теорія, методологія, практика : монограсрія. Одеса : Атлант, 2015. 365 с.

10. Федяй Н. О. Правове поле стратегічного управління регіональним розвитком в Україні. Економіка $i$ прогнозування. 2012. № 4. С. 54-62.

\section{REFERENCES:}

1. Beketov N. V. (2008) Problemy strategicheskogo planirovaniya regional'nym razvitiem [Problems of strategic planning of regional development]. Regional'naya ekonomika: teoriya i praktika - Regional Economics: Theory and Practice, no. 35, pp. 15-19. (in Russian)

2. Datsii O. I. (2017) Innovatsii - osnovna diiucha syla naukovo-tekhnichnoho prohresu dlia zberezhennia pryrodnoho seredovyshcha [Innovation is the main driving force of scientific and technological progress for the preservation of the natural environment]. Ekonomika ta derzhava - Economy and State, no. 5, pp. 4-9. (in Ukrainian)

3. Drobenko H. O., Brusak R. L., Svirskyi Yu. I. (2001) Stratehichne planuvannia rozvytku terytorialnykh hromad [Strategic planning of development of territorial communities]. Lviv: Spolom, 118 p. (in Ukrainian) 
4. Kontseptsiia vdoskonalennia systemy prohnoznykh i prohramnykh dokumentiv z pytan sotsialno-ekonomichnoho rozvytku Ukrainy: Rozporiadzhennia Kabinetu Ministriv Ukrainy [The concept of improving the system of forecast and program documents on socio-economic development of Ukraine: Order of the Cabinet of Ministers of Ukraine] of 04.10.2006 № 504-r / Verkhovna Rada Ukrainy - Verkhovna Rada of Ukraine. Retrieved from: https://zakon2.rada.gov.ua/laws/show/504-2006-\%D1\%80 (accessed 20 October 2021). (in Ukrainian)

5. Kuksa I. (2016) Stratehichne planuvannia sotsialno-ekonomichnoho rozvytku rehionu [Strategic planning of socio-economic development of the region]. Visnyk Skhidnoukrainskoho natsionalnoho universytetu im. V. Dalia Bulletin of the V. Dahl East Ukrainian National University, no. 17 (171), pp. 218-224. (in Ukrainian)

6. Pro derzhavne prohnozuvannia ta rozroblennia prohram ekonomichnoho ta sotsialnoho rozvytku Ukrainy: Zakon Ukrainy [On state forecasting and development of programs of economic and social development of Ukraine: Law of Ukraine] of 23.03.2000 № 1602-III / Verkhovna Rada Ukrainy - Verkhovna Rada of Ukraine. Retrieved from: https://zakon.rada.gov.ua/laws/show/1602-14 (accessed 20 October 2021). (in Ukrainian)

7. Reforma publichnoho upravlinnia v Ukraini: vyklyky, stratehii, maibutnie (2009) [Public administration reform in Ukraine: challenges, strategies, future] / edited by I. A. Hrytsiak. Kyiv: «K.I.S.», 240 p. (in Ukrainian)

8. Rozvytok partnerstva mizh mistsevoiu vladoiu ta nederzhavnym sektorom u sferi nadannia hromadskykh posluh (2003) [Development of partnerships between local authorities and the non-governmental sector in the field of public services] / edited by Yu. P. Lebedynskyi. Uzhhorod: Patent, 192 p. (in Ukrainian)

9. Smentyna N. V. (2015) Stratehichne planuvannia sotsialno-ekonomichnoho rozvytku na mezorivni: teoriia, metodolohiia, praktyka [Strategic planning of socio-economic development at the meso level: theory, methodology, practice]. Odesa: Atlant, 365 p. (in Ukrainian)

10. Fediai N. O. (2012) Pravove pole stratehichnoho upravlinnia rehionalnym rozvytkom v Ukraini [Legal field of strategic management of regional development in Ukraine]. Ekonomika i prohnozuvannia - Economics and Forecasting, no. 4, pp. 54-62. (in Ukrainian) 